\title{
An Agency Perspective on Firm Diversification, Efficiency and Performance: Evidence From Malaysia
}

\author{
Sin-Huei $\mathrm{Ng}^{1}$, Tze San Ong ${ }^{2} \&$ Boon Heng $\mathrm{Teh}^{3}$ \\ ${ }^{1}$ School of Economics and Management, Xiamen University Malaysia, Sepang, Malaysia \\ ${ }^{2}$ Faculty of Economics and Management, Universiti Putra Malaysia, Serdang, Malaysia \\ ${ }^{3}$ Faculty of Management, Multimedia University, Cyberjaya, Malaysia \\ Correspondence: Sin-Huei Ng, School of Economics and Management, Xiamen University Malaysia, Bandar \\ Sunsuria, 43900, Sepang, Selangor Darul Ehsan, Malaysia. Tel: 60-3-8705-5037.
}

Received: June 18, 2019

Accepted: July 23, 2019

Online Published: August 8, 2019

doi:10.5430/ijfr.v10n6p24

URL: https://doi.org/10.5430/ijfr.v10n6p24

\begin{abstract}
We examine, from the agency perspective, the relationship between three important corporate measures among the Malaysian publicly-listed family-controlled firms: firm diversification, asset utilization efficiency and firm performance. We also explore the role of board independence in moderating the firm diversification-performance relationship. Our findings suggest that the greater the extent of firm diversification, the poorer will the asset utilization efficiency be. The poorer efficiency is likely to have caused the equally poorer performance for the firms in our findings. Notably, firm diversification is found to be more detrimental to performance for those firms affiliated to business group compared to firms without group affiliation. The group-affiliated firms which are found to be more diversified than the non-group firms, could have engaged in greater diversification for the self-interest of the controlling family. Specifically, we find that the agency-driven diversification causes the ROA (Tobin's Q) of the firms to be lowered by $0.354 \%$ (0.026) for every additional increase in the number of business segments as the measure of firm diversification. In terms of the moderating effect of board independence, our finding shows that audit committee of board comprises entirely of independent outside directors positively moderate the firm diversification-performance linkage and is capable of reversing the apparently negative linkage between the two.
\end{abstract}

Keywords: firm diversification, efficiency, performance, business group, agency problem, board independence

\section{Introduction}

Family firms may be more inclined to reduce their risk exposure in the business because usually a significant proportion of the wealth of the owners is tied to their business (García-Kuhnert, 2015; Jiang et al., 2015). One such strategy to reduce risk is to diversify into various business lines. Should a market segment not perform well, there are always other business segments to cover the losses. Chinese family firms in South East Asia (including Malaysia) have a tendency to diversify, as many of them are more widely diversified compared to firms from the West (Bruton et al., 2003). According to Claessens and Fan (2002), firm diversification is among several corporate governance issues underlying concentrated ownership structures which are specific to Asia, or at least more important in Asia.

Previous research has suggested that firms in Asia have been active in using firm diversification for private benefits and entrenchment. Thus agency problems can be different within diversified firms (Claessen et al., 2002; Mitton, 2002). The lower transparency of diversified firms in emerging economies gives rise to a higher level of asymmetric information that may allow owner-managers or controlling families to take advantage of minority shareholders with ease (Lins and Servaes, 2002; Lins, 2003; Ng et al., 2012; Baran and Forst, 2015). Mitton (2002) documented that loss in firm value could be particularly pronounced for firms with high diversification during periods of economic or financial crisis. This implies that expropriation of minority shareholders increases in diversified firms during periods of crisis (Mitton, 2002). Expropriation is a defined by Claessens et al. (2000) as the process of using one's control powers to maximize own welfare and redistribute wealth from others.

Amihud and Lev (1981) and Denis et al. (1997) also point out that one of the possible ways for managers (including family-managers) to create private benefits is to diversify across various industries. Diversification may be regarded as management's 'perquisite consumption' because of the probable direct relationship between diversification and 
reduction in business risk as well as larger managerial compensation. Business risk is defined as uncertainty of earnings over time due to changes in industry-specific factors. Reduction in business risk via diversification is particularly important for a controlling family, to diminish the exposure of the family's wealth to industry risks (Andres, 2008). However, from the perspective of minority shareholders, risk reduction through firm diversification across industries may not be a value-added move, simply because it is more efficient and effective to go for stock portfolio diversification (Ross et al., 2015).

Diversification into various areas of business is also generally regarded as one of the factors that caused the 1997 Asian Financial Crisis (AFC) to be more detrimental than expected (Fatimah, 2001). Chu (2007), in his study of ownership structure and rent-seeking in the Malaysian manufacturing sector also points out that diversification is among the mechanisms that can be used to expropriate shareholder value, especially when the controlling families' interest is comparatively large and the industries involved have low intensity of competition. Using a sample of 355 listed firms for the year 2000, Zuaini and Napier (2006), in their study of ownership structure and firm diversification, find that the control rights of controlling shareowners are significantly negatively associated with the 'excess value' of the firms, suggesting that expropriation increases with control rights. Their study however does not focus on family-controlled firms.

Within the corporate sector, forming business groups is a common practice in family businesses in Malaysia. A family-controlled business group is formed when two or more publicly-listed firms are simultaneously controlled by the same family. Family-controlled business groups in Malaysia often operate across a diversified range of activities within a sector, as well as across many sectors as diverse as plantation, manufacturing, trading, services, construction and property development. The formation of business groups by controlling families can bring additional agency problems which do not exist in Anglo-Saxon countries, particularly in US and UK corporations (Morck and Yeung, 2003). One of these agency problems is excessive diversification which could inversely affect the efficiency with which firms utilize their assets and subsequently the performance of the firms. This issue has not been sufficiently studied in the context of Malaysian family-controlled business group and it is the intention of this study to fill the gap. We also intend to examine how the firm diversification-performance linkage could be affected by board independence. More discussion is devoted on the issue in the sections that follow.

Based on the above, our objectives are: a) To examine the linkage between firm diversification, efficiency and performance, $b$ ) To explore whether there is a difference in the issue examined in part a) between firms with business group affiliation and firms without group affiliation, c) To explore the moderating effect of board independence on the diversification-performance relationship. The remainder of the paper is organized as follows: literature review and hypothesis development are provided in Section 2. This is followed by Section 3 on methodology. Our findings and discussion are presented in Section 4 and conclusions with suggestion for future study are provided in Section 5.

\section{Literature Review and Hypothesis Development}

\subsection{Firm Diversification and Performance}

The literature on corporate firm diversification is voluminous, diverse and ever-growing. One of the most important areas of firm diversification research is concerned with the relationship between diversification and firm performance. Two important survey papers, Martin and Sayrak (2003) and Palich et al. (2000), show continuing interest exists in the subject of diversification-performance among researchers. Though there is no lack of prior literature on the diversification-performance link, limited research work, especially in Malaysia, has been undertaken on the roles of board independence in influencing the diversification-performance link. This element of the diversification-performance link research is still lacking and this study intends to fill the gap in the literature.

According to Gomez (2006), using diversification to expand a business has been a popular strategy for corporations in Malaysia ever since the British colonial period: "Chinese immigrants (in Malaya) diversified into any field that held out the prospect of high returns" (Gomez, 2006, p.124), and "Bumiputeras (the indigenous Malays) who controlled quoted companies began doing the same in the 1980s" (Gomez, 2006, p.124). Prior to 1997, before the AFC, there were signs of over-diversification in many firms in Malaysia. Most of these firms took the opportunity of the availability of relatively low-cost credit and bank loans to finance their expansion and diversification (Fatimah, 2001). Many firms were reported to have a very high debt-to-equity ratio prior to the AFC (Chu and Song, 2011; Suto, 2003).

Initially, diversification is believed to have some economic and strategic value (Mehmood et al., 2019). However, over time, as firms are ambitiously involved in diversification, it is possible they will be diversified beyond their core competencies and capabilities - into unrelated businesses. The manager-owners could increase diversification to 
boost the chances of inefficient reallocation of resources, transfer pricing, insider trading or other activities that protect the interests of the controlling families which subsequently leads to lower firm value (Chu, 2007). Lien and $\mathrm{Li}$ (2013) find that controlling family ownership in Taiwanese firms is significantly associated with a greater extent of diversification, which impairs firm value. Early works such as Palepu (1985) show that firms with unrelated diversification are less profitable than firms without unrelated businesses. Some researchers argue that excessive diversification is a reflection of poor corporate governance mechanisms.

From the agency perspective, it is argued that additional power, self-pride, prestige and size-related managerial compensation are all examples of private benefits that can be derived from firm diversification (Jensen, 1986). Demsetz and Lehn (1985) find that diversification allows controlling shareholders to derive greater insider information and additional 'profits' from insider trading activities in the form of both pecuniary and non-pecuniary private benefits.

Singh et al. (2007) argue that: “...in emerging markets where proper monitoring mechanisms do not exist, market based checks and balances are absent, and an active market for corporate control is practically non-existent, agency led diversification may be a strong possibility" (p.340). This is especially true in a corporate sector which is dominated by family firms and family business groups with "almost unchecked power and financial strength" (p.340).

In Malaysia, diversification is a way for a firm to expand and become larger; larger firms stand a better chance to form 'relationships' with political figures and 'work together' with them for quid-pro-quo benefits (for instance receiving political patronage for controlling shareholders and funds for politicians and their ruling political party). The information compiled by Gomez and Jomo (1997) and $\mathrm{Ng}$ and Yeoh (2012) shows that many of the firms which are politically well connected to high-ranking political figures are larger firms or business groups that are widely diversified.

Asian (including Malaysian) corporations are well known for extensive diversification (Claessens and Fan, 2002). Claessens et al. (2003) find that about $70 \%$ of Malaysian firms pursued diversification that led to misallocation of capital and resources and were thus inefficient. The danger of extensive diversification is that it may result in manager-owners expanding the firm beyond what is sensible, affecting firm performance. Examples of insensible motives of diversification include empire-building and the participation in pet projects (Thillainathan, 1999).

In Anglo-Saxon countries, it is asserted that diversification is the main reason for the stock value of conglomerates being traded at a discount (Al-Maskati et al., 2015). One of the causes of discounting is agency problem (Amihud and Lev, 1999; Denis et al., 1999). However, the reason why agency problem could cause diversification discount is unclear. From the agency theory perspective, the intention of management to diversify could be due to the empire-building mindset. 'Diversification discount', as reported in the literature, is generally interpreted as evidence of misalignment between the managers' behaviour and shareholders' interests and therefore is an example of agency problem in the corporate governance of the firms (Bru and Crespi-Cladera, 2006; Al-Maskati et al., 2015). Over-diversification could be a reflection of unscrupulous investment behaviour of managers (Jensen, 1986). The consequences of ill-intended diversification are declining firm performance and destroyed firm value. Yet Fauver $e t$ al. (2003) do not find evidence to support diversification discount in developing countries even though it is documented in developed countries. Firm diversification might bring more benefits than costs in emerging economies.

From resource-based view, diversification can provide resources and capabilities that are transferable across various divisions of a firm (Martin and Sayrak, 2003). It also creates value by mitigating failures in product, labour and capital markets in less developed countries by replicating the functions of institutions that are 'missing' in those countries (Khanna and Palepu, 2000a). Khanna and Palepu (2000a) find that, in India, an increase in diversification can reduce transaction costs and improve firm performance. Also, diversification may ease firms' access to external markets and allow them to borrow more, at a cheaper cost. This is because different cash flows among divisions could cancel out each other's cash flow fluctuations and stabilize the overall cash flows of the entire firm (Lewellen, 1971). From the perspective of creditors, the risk-reduction creates what Lewellen (1971) calls the 'co-insurance' of diversification where the lending has a lower default risk. Nevertheless, excessive borrowing in diversified firms is considered to be one of the factors which contributed to financial distress and bankruptcy in many firms during the 1997 AFC (Claessens et al., 1998a and 1998b).

Chu and Song (2011) study the connections between firm diversification, capital structure and the role of large shareholders in Malaysian firms. They find diversification to be non-linearly related to firm value in which a low level of diversification improves firm value and a high level of diversification destroys firm value. However, by 
covering only the manufacturing industry with sample data collected from the period 1994 to 2000, before corporate governance reform became effective in Malaysia, Chu and Song's study is rather narrow in scope (Note 1).

Using a sample of 355 listed companies, Zuaini and Napier (2006) investigate the relationship between diversification and firm value in Malaysia. In contrast to what is claimed by some, their overall result shows no evidence of lower value for firms with a higher degree of diversification. Chakrabarti et al. (2007) do not find any relationship between firm diversification and performance in Malaysia and Thailand, both economies with relatively weak institutions (e.g. the regulatory institutions), whereas they find that diversification is positively related to return on assets (ROA) for Indonesia, the economy with the least developed institutions and finally a negative relationship in the case of Japan and Korea, both with relatively developed institutional environments. They conclude that diversification is therefore beneficial only in economies with "substantially underdeveloped institutional environments" (Chakrabarti et al., 2007, p.111), whereas diversification is harmful in more developed institutional environments. Lee et al. (2008) contend that the 'diversification premium' caused by the imperfection of input and product markets [known as 'institutional voids' by Khanna and Palepu, (2000a, 2000c)], as documented in some past studies of emerging economies, is not likely to stand the test of time. The findings of their study in Korea from 1984 to 1996 have empirically shown that as the markets in Korea developed and underwent institutional transition during the period, the premium enjoyed by diversified firms had gradually dissipated over time and was eventually replaced by 'diversification discount'.

Based on the above discussion, 'diversification premium' could have been replaced with 'diversification discount' in the context of Malaysian firms as close to two decades had passed after the Asian Financial Crisis wherein progress has been made with regards to corporate governance development. Therefore, on balance, it is acceptable to expect that the effect of diversification on firm performance is likely to be negative. Thus,

Hypothesis 1a: Diversified firms underperform focused firms.

Hypothesis 1b: The greater firm diversification is across industries or business segments, the lower is firm performance.

\subsection{Is Firm Diversification Agency-Driven?}

According to Singh et al. (2007) and Al-Maskati et al. (2015), one of the possibilities of poorer performance of diversified firms associated with diversification discount, as documented in past studies, is higher agency problems in these diversified firms. If diversification is agency-driven, then a negative relation will be expected between asset utilization efficiency and the degree of diversification.

According to Ang et al. (2000), asset utilization efficiency can be measured by the asset turnover ratio (total sales/total assets) of firms. The ratio indicates how effectively owner-managers deploy the firm's assets. This ratio is also used as a proxy for agency costs in Florackis (2008), Singh and Davidson (2003) and Fleming et al. (2005) and the explanation provided is that "(a) low asset turnover ratio may indicate poor investment decisions, insufficient effort, consumption of perquisites and purchase of unproductive products (e.g. office space)" (Florackis, 2008, p.45).

Moreover, since the conflict of interests between owner-managers and minority shareholders in business group-affiliated firms may be more serious than non-group affiliated firms, as highlighted earlier, the negative relationship between asset utilization efficiency and firm diversification could be stronger in these firms compared to non-group firms. Thus, the following hypothesis is proposed:

Hypothesis 2: Asset utilization efficiency is negatively related to the degree of firm diversification because firm diversification is agency-driven and this relationship is stronger for group-affiliated firms than non-group firms.

\subsection{Firm Diversification and Board Independence}

Generally, agency theory believes that more independent boards will protect shareholders' interests such as constraining the over-pursuit of diversification strategies by the managers (Anderson et al., 2000, Gleason et al., 2012; Wilson et al., 2013). Accordingly, compared to management-dominated boards, it is reasonable to expect that independent boards are linked to relatively lower levels of diversification. Bru and Crespi-Cladera (2006) find that group-affiliated firms with more family members on the board tend to have higher diversification compared to comparable firms with less family members on the board. In contrast, Chen et al. (2009) believe that corporate decisions such as diversification are generally made by management without direct participation of the board. Thus the asymmetric information between management and independent directors prevents the latter from acting independently and making informed decisions. 
Chen et al. (2009), who investigate the association between the composition of the board of directors (including board independence) and firm diversification in Australia, a developed economy, find that there is no link between the two. Specifically, they do not find evidence to show that a more independent board improves profitability and promotes shareholders' interests in the form of reduced firm diversification. Thus they suggest revising the current requirement or recommendation in many jurisdictions that boards be more independent. They add that "board composition should also consider directors' knowledge, relevant expertise, availability, and length of tenure" (Chen et al., 2009, p.208). For instance, tenure of independent directors should be examined by regulators because over time, independence may be compromised (Chen et al., 2009).

However, as an emerging economy, at this stage in its development of corporate governance, Malaysia still lags behind Australia and thus the findings in Australia by Chen et al. (2009) may only serve as a reference and are not directly applicable to Malaysia. On-going efforts by the authorities are still needed to enhance board independence in this country, as they explore other aspects of how a board could increase overall efficiency. A highly independent board may help a firm to curb unscrupulous, dubious and value-destroying diversification but nonetheless support diversifications that are sensible or value-adding and vice versa for boards with low independence. In other words, board independence may moderate the effects of strategic decisions such as diversification on firm performance. Thus it is conjectured that:

Hypothesis 3: Board independence positively moderates the effect of firm diversification on firm performance.

\section{Method}

\subsection{Data Selection and Measures}

A total of three hundred fourteen family-controlled firms were selected in 2010 from the firms listed on the Main Board of Bursa Malaysia based on Krejcie and Margan (1970) approach. The criterion used to define a firm as family-owned and controlled is based on the ' $10 \%$ cut-off level' definition used in two often cited influential studies: La Porta et al. (1999) and Claessens et al. (2000). According to the studies, using the $10 \%$ cut-off level, a corporation is said to have an ultimate controlling shareholder if this shareholder's direct and indirect voting rights in the firm exceed 10\% (La Porta et al., 1999). Firms are known as family-controlled in this study if one or more family members are collectively identified as the largest shareholders of the firm and own at least a $10 \%$ equity stake of the company.

We also define group-affiliated firms in this study as firms that are under the control of the same or common controlling family. Control can be achieved by the controlling family either by direct or indirect holding of shares through another corporation(s) (which can be publicly-listed or privately-held). In short, publicly listed firms that share the same controlling family is considered as affiliated to the same family business group. Information pertaining to corporate ownership and whether a firm is affiliated to a business group is traced and obtained from the respective company annual reports. Of three hundred fourteen family-controlled firms in our sample, one hundred and fifty-two of them are group-affiliated and the remaining one hundred sixty-two firms are considered as non-group firms.

Board of directors related information is obtained from the company annual reports whereas other data needed for the study including the market value and book value of ordinary shares, total debts, earnings before interest, taxes, depreciation and amortisation (EBITDA), total assets, year of firm incorporation (firm age) and total sales, are obtained from the Worldscope database.

Due to the lack of consensus in the literature with regard to the choice of firm performance measure, it is thus difficult to identify a single indicator for firm performance. We opt to use both the accounting-based return on assets (ROA) and the stock-market-based simplified Tobin's Q as the proxies to measure firm performance. It is intended that using alternate measures also helps to verify the robustness of the results (Haniffa and Hudaib, 2006). Both measures are widely used as the only performance measures in the past studies (such as in Khanna and Palepu, 2000a; Anderson and Reeb, 2003; Haniffa and Hudaib, 2006; George and Kabir, 2008; Andres, 2008; Masulis et al., 2011) (Note 2).

ROA is defined as earnings before interest, taxes, depreciation and amortization (EBITDA) divided by book value of total assets. EBITDA is used to assess the operating efficiency of firms without being influenced by debt policy and associated amounts of interest. The simplified Tobin's Q is defined as the sum of market value of equity and book value of total liability divided by the book value of total assets (Mak and Kusnadi, 2005). Data on both ROA and Tobin's Q are winsorized at the $1^{\text {st }}$ and $99^{\text {th }}$ percentiles as per the practice in similar literature (e.g. Chen and Chen, 2012; Guest and Sutherland, 2010; Salkind, 2010). 


\subsection{Diversification Measures}

For the purpose of constructing firm diversification variables, two sets of diversification-related data are collected: the number of business segments of firms, which is collected from the company annual reports, and segmental sales values which are obtained from the Worldscope database. Data from Worldscope is randomly cross-checked with company annual reports to verify accuracy. We employ four types of diversification measures below in order to improve the robustness of the findings due to controversy surrounding the appropriateness of different measures of firm diversification as highlighted by Robins and Wiersema (2003):

(i) Dummy variable - firms are classified as 'diversified' or 'focused' based on the number of segments disclosed. Firms that fulfil the following conditions are classified as diversified: with more than a single segment and where the sales in the largest segment are less than $90 \%$ of total sales. Firms that do not fulfil the conditions are classified as focused (Claessens et al., 1999c; Fauver et al., 2003; Lins and Servaes, 2002).

(ii) The number of business segments as disclosed in the annual reports. This measure is used in Denis et al. (1997) and Zuaini and Napier (2006).

(iii) The Herfindahl $(\mathrm{H})$ Index -a common measure used in many previous studies examining diversification issues (such as Chen and Ho, 2000; Denis et al., 1997; Lang and Stulz, 1994). It is calculated as follows for each firm $i$ :

$\mathrm{H}=\Sigma\left(\right.$ Sales per segment/Total sales) ${ }^{2}$

The $\mathrm{H}$ Index ranges from 0 to 1 . The closer it is to 0 , the greater the firm diversification.

(iv) The Entropy (E) measure - introduced by Jacquemin and Berry (1979) and Palepu (1985) and widely used by previous studies, for instance in Singh et al. (2007), Chakrabarti et al. (2007) and Kim et al. (2008). It is calculated as follows for each firm $i$ :

$$
\mathrm{E}=\sum_{i=1}^{n} P i \ln \left(1 / P_{i}\right)
$$

Where $P_{i}$ is the $i$ th business segment's sales divided by the firm's total sales, and $n$ is number of firm's business segments. $\ln \left(1 / P_{i}\right)$ is the logarithm of the inverse of a business segment's sales over the total sales. The higher the $\mathrm{E}$, the greater the firm diversification is.

We also use the following two measures to indicate board independence in our study: Proportion of Independent Non-executive Directors on Board (Note 3), and dummy variable Audit Committee consists of All Independent Outside Directors. Both variables serve as moderator variable to examine the moderating effects of board independence on the relationship between firm diversification and performance.

We include several control variables that are considered important in affecting firm performance. These variables are firm size, age, gearing ratio and sector classification (based on Bursa Malaysia's sector classification system). They are frequently used as control variables in multiple regression analysis in relevant literature. For instance, the control variables used in Khanna and Palepu (2000a), Douma et al. (2006) and George and Kabir (2008) are very similar to those mentioned above.

Multiple regressions based on ordinary least square (OLS) estimation technique are used to test the hypotheses in this study. Previous comparable studies such as Masulis et al. (2011), Claessens et al. (2006) and Khanna and Palepu (2000a) also rely on OLS in their analyses. OLS is reliable as long as common regression problems are accounted for. Issues commonly associated with regression such as normality, multicollinearity and heteroscadasticity are addressed in the study using appropriate steps or measures (Note 4).

\subsection{Specifications}

The following regression specification is used to examine the hypothesis on the effect of firm diversification on performance (PFM):

$$
\mathrm{PFM}_{\mathrm{i}}=\alpha+v \mathrm{DVF}_{\mathrm{i}}+\theta \mathrm{X}_{\mathrm{i}}+\varepsilon_{\mathrm{i}}
$$

Where: DVF is firm diversification measured by the four diversification measures respectively: Diversification Dummy, Number of Business Segments, H Index, and Entropy. Alpha $(\alpha)$ is the constant term, $\varepsilon$ is the error term and subscript $i$ denotes individual firms. Our focus is on the coefficient value, $v$, in which a positive value for $v$ (for $\mathrm{H}$ index) or a negative value for $v$ (for the 'Diversification Dummy', 'Number of Segments' and 'Entropy' measures) is 
an indication of a negative association between the level of firm diversification and performance, and vice versa. $\mathrm{X}$ is a vector of other control variables, namely firm size, age, group, gearing and business sector effects.

In order to test whether firm diversification is agency-driven, the following regression specification is used. This specification is also used separately to test the hypothesis for group-affiliated firms and non-group firms:

$$
\operatorname{Ln}(\text { Efficiency })_{i}=\alpha+\beta{D V_{F}}_{i}+\theta X_{i}+\varepsilon_{i}
$$

(Specification 2)

Where: Efficiency refers to 'Asset Utilization Efficiency' which is measured by the asset turnover ratio (Total Sales/Total Assets). The variable is transformed using natural $\log (\mathrm{Ln})$ since it leads to better statistical characteristics (Fleming et al., 2005). A negative value for coefficient $\beta$ indicates that higher diversification is associated with a lower asset turnover ratio and suggests that diversification is agency-driven. $\mathrm{X}$ is a vector of control variables that includes firm size, age, gearing, group, ROA and business sector effects. The inclusion of these control variables is consistent with those in Fleming et al. (2005).

Finally, regression specification below with the interaction terms $\left(\mathrm{DVF}_{\mathrm{i}}{ }^{*}{ }^{*} \mathrm{BND}_{\mathrm{i}},{ }\right)$ included to examine the moderating effects of board independence on the diversification-performance link:

$$
\mathrm{PFM}_{\mathrm{i}}=\alpha+v \mathrm{DVF}_{\mathrm{i}}+\delta \mathrm{BIND}_{\mathrm{i}}+\gamma \mathrm{DVF}_{\mathrm{i}} * \mathrm{BIND}_{\mathrm{i}}+\theta \mathrm{X}_{\mathrm{i}}+\varepsilon_{\mathrm{i}} \quad \text { (Specification 3) }
$$

where the new variable BIND refers to board independence.

\section{Findings and Discussion}

For ease of reference, a list of abbreviations used in this study, together with a definition/explanation, is presented in Table 1 below.

\begin{tabular}{|c|c|c|}
\hline Abbreviation & Variable & Operationalization \\
\hline ROA & Return on Assets & EBITDA / Total assets \\
\hline Tobin's Q & Simplified Tobin's Q & $\begin{array}{l}\text { (Market value of equity }+ \text { Book value of total } \\
\text { liability) / Book value of assets }\end{array}$ \\
\hline INED & Proportion of Independent Directors & $\begin{array}{l}\text { Number of independent directors / Total number of } \\
\text { directors on the board }\end{array}$ \\
\hline INDP_ADT & Independent Audit Committee & $\begin{array}{l}\text { Dummy is } 1 \text { if all the audit committee members are } \\
\text { independent directors; } 0 \text { otherwise. }\end{array}$ \\
\hline Group & Business Group-affiliated & $\begin{array}{l}\text { Dummy is } 1 \text { if the firm is affiliated to a business } \\
\text { group; zero otherwise. A firm is considered as } \\
\text { group-affiliated if it shares the same controlling } \\
\text { family with other publicly-listed firm(s). }\end{array}$ \\
\hline $\mathrm{E}$ & ENTROPY or E value & $\begin{array}{l}\mathrm{E}=\sum \mathrm{P}_{\mathrm{i}} \mathrm{Ln}\left(1 / \mathrm{P}_{\mathrm{i}}\right) \text { where } \mathrm{P}_{\mathrm{i}} \text { is the } \mathrm{i} \text {-th business } \\
\text { segment's sales divided by the firm's total sales. The } \\
\text { higher the } \mathrm{E} \text {, the greater the firm diversification. }\end{array}$ \\
\hline HERF & Herfindahl or H Index & $\begin{array}{l}H=\Sigma(\text { Sales per segment/Total sales })^{2} \text {. The lower the } \\
H \text {, the greater is firm diversification. }\end{array}$ \\
\hline NUM_SEG & Number of Segments & $\begin{array}{l}\text { Number of business segments as reported in } \\
\text { company annual reports. }\end{array}$ \\
\hline DVSF_D & Diversification Dummy & $\begin{array}{l}\text { Dummy is } 1 \text { if the firm has more than a single } \\
\text { business segment and where the sales in the largest } \\
\text { segment are less than } 90 \% \text { of total sales; } \\
\text { otherwise. }\end{array}$ \\
\hline Efficiency & Asset Turnover Ratio & Total sales / Total assets \\
\hline Sales & Total Sales & Total sales or revenues in Ringgit Malaysia \\
\hline Gearing & Gearing Ratio & Total debts / Total assets \\
\hline
\end{tabular}

Table 1. List of abbreviations, variables and operationalization 
Panel A of Table 2 shows the key statistical features of diverse measures of diversification used in this study. The mean (median) values of the Entropy, H Index and Number of Segments are 0.420 (0.360), 0.763 (0.813) and 2.69 (2.5) respectively. As a comparison, Zuaini and Napier (2006) report a Herfindahl Index of 0.71 and an average number of 2.36 segments from their sample of 355 Malaysian firms in 2001, whereas Ayoib et al. (2003) report an average number of 2.30 segments from their sample of 219 Malaysian firms in 1995. This suggests that the firm diversification scenario has changed little since before the 1997 Asian Financial Crisis.

Table 2. Descriptive statistics

\begin{tabular}{|c|c|c|c|c|c|}
\hline \multicolumn{6}{|l|}{ Panel A: Diversification } \\
\hline Variable & Mean & Median & Maximum & Minimum & Standard Deviation \\
\hline Entropy & 0.420 & 0.360 & 1.630 & 0.000 & 0.415 \\
\hline Herfindahl & 0.763 & 0.813 & 1.000 & 0.225 & 0.235 \\
\hline Number of Segments & 2.690 & 2.500 & 9.000 & 1.000 & 1.598 \\
\hline Number of Firms with: & & \multicolumn{2}{|c|}{ Group-affiliated firms } & \multicolumn{2}{|c|}{ Non-group firms } \\
\hline One business segment & & \multicolumn{2}{|l|}{47} & \multicolumn{2}{|c|}{55} \\
\hline Two business segments & & \multicolumn{2}{|l|}{18} & \multicolumn{2}{|c|}{37} \\
\hline Three business segments & & \multicolumn{2}{|l|}{28} & \multicolumn{2}{|c|}{31} \\
\hline Four and above business segments & & \multicolumn{2}{|l|}{59} & \multicolumn{2}{|c|}{39} \\
\hline Total & & \multicolumn{2}{|l|}{152} & \multicolumn{2}{|c|}{162} \\
\hline Diversification Dummy & & \multicolumn{2}{|l|}{$1=153$ firms } & \multicolumn{2}{|c|}{$0=161$ firms } \\
\hline \multicolumn{6}{|l|}{ Panel B: Asset Utilization Efficiency } \\
\hline Variable & Mean & Median & Maximum & Minimum & Standard Deviation \\
\hline $\begin{array}{l}\text { Asset Utilization Efficiency } \\
\text { (asset turnover ratio) }\end{array}$ & 0.829 & 0.729 & 6.873 & 0.035 & 0.659 \\
\hline \multicolumn{6}{|l|}{ Panel C: Board Independence } \\
\hline Variable & Mean & Median & Maximum & Minimum & Standard Deviation \\
\hline \multirow[t]{2}{*}{ INED } & 0.43 & 0.41 & 0.75 & 0.22 & 0.11 \\
\hline & Yes (1) & Percentage & No $(0)$ & & Percentage \\
\hline INDP_ADT & 99 Firms & 31.5 & 215 Firms & & 68.5 \\
\hline
\end{tabular}

\subsection{Descriptive Statistics}

Our diversification data also show that, of the 152 firms affiliated to business group, close to forty percent of them operate with four or more business segments as opposed to only twenty-four percent in the non-group firms. This suggests that group-affiliated firms are more diversified than non-group firms. This observation is consistent with Lin and Servaes (2002), who find that group firms are more likely to be diversified compared to non-group firms

The diversification dummy variable shows that 153 firms (or $49 \%$ of firms) are considered as diversified, whereas 161 firms (or 51\% of firms) are considered as non-diversified or focused firms. As a comparison over time, using 2001 data, Zuaini and Napier (2006) report that 55\% of their 355 sample firms in Malaysia are diversified and 45\% are focused, whereas Claessens et al. (2003) based on the data in the period 1990-1996 before the Asian Financial Crisis, discover that $70 \%$ of their sample firms from Malaysia are diversified. This may indicate that the percentage of focused firms has increased over the years since the AFC close to two decades ago.

The statistics on Asset Utilization Efficiency (asset turnover ratio) in Panel B show that the average asset turnover ratio is about 0.83 (with maximum value $=6.87$ and minimum value $=0.035$ ). Asset turnover ratio depends substantially on the type of business sector; thus the inclusion of 'business sector' as a control variable in the regression analysis is crucial. 
Panel C shows the data on the two measures of board independence: the percentage of independent non-executive directors in the board of directors (INED) and the dummy variable, Independent Audit Committee (INDP_ADT). On average, about $43 \%$ of board directors are categorized as independent non-executive directors (INED). This percentage is above the one-third independent directors requirement set by the Malaysian Code on Corporate Governance (MCCG). The highest percentage of independent directors in the sample firms is $75 \%$ (71\% in group-affiliated firms). Dummy variable INDP_ADT shows that 99 family-controlled firms (or about $32 \%$ of the firms in our sample) have their audit committee members consisting of only independent non-executive directors.

Finally, we also perform the correlation matrix before the multiple regression analysis is conducted with the purpose of checking for potential multicollinearity between the explanatory variables as well as the 'one-to-one relationship' between the dependent and explanatory variables. No serious multicollinearity is identified from the matrix (Note 5).

\subsection{Analysis for Specification 1}

The association between firm diversification and performance is examined and presented in Table 3. Four measures of firm diversification are employed for the purpose. All four diversification measures show that firm performance (in both ROA and Tobin's Q) is negatively related to firm diversification, especially in Tobin's Q where the negative relationship is sufficiently strong, statistically.

Table 3. Firm diversification and performance

\begin{tabular}{|c|c|c|c|c|c|c|c|c|}
\hline & ROA & & & & Tobin's Q & & & \\
\hline Variable & (1) & (2) & (3) & (4) & (5) & (6) & (7) & (8) \\
\hline ENTROPY & $-1.220^{*}$ & & & & $-0.087 * *$ & & & \\
\hline HERF & & 2.034* & & & & $0.119 *$ & & \\
\hline NUM_SEG & & & $-0.354 *$ & & & & $-0.026 * *$ & \\
\hline DVSF_D & & & & -0.155 & & & & -0.015 \\
\hline Group & $-1.848 * *$ & $-1.864 * *$ & $-1.833 * *$ & $-1.913 * *$ & $-0.043^{*}$ & -0.045 & $-0.042^{*}$ & -0.048 \\
\hline Adjusted $\mathrm{R}^{2}$ & 0.276 & 0.275 & 0.276 & 0.272 & 0.181 & 0.177 & 0.184 & 0.171 \\
\hline F-statistic & $8.005 * * *$ & $7.993 * * *$ & $8.028 * * *$ & $7.864 * * *$ & $5.067 * * *$ & $4.954 * * *$ & $5.140 * * *$ & $4.790 * * *$ \\
\hline Observations & 314 & 314 & 314 & 314 & 314 & 314 & 314 & 314 \\
\hline
\end{tabular}

Note: $1 . *$ significant at $10 \%$; ** significant at $5 \%$; ***significant at $1 \%$.

2. The values in the table show the coefficients of the variables.

3. Control variables and sector effects are included in the regression (not shown above except for 'Group').

The finding suggests that market-based performance (Tobin's Q) is more susceptible to firm diversification compared to accounting-based performance (ROA). It implies that the market does not respond well to firm diversification. In general, the greater the firm diversification of a firm, the greater it will see its market value being marked down. Diversification could have been practiced, as the market sees, mainly to enhance the interest of controlling families, for instance, by reducing the risk of their undiversified family wealth. In other words, the reduction in firm and industry-specific risks as a result of firm diversification mainly benefits the controlling family and not the minority shareholders. Moreover, minority shareholders can always reduce their exposure to firm-specific risks through portfolio diversification (Ross et al., 2015; Claessens et al., 1999c). The market may be concerned about controlling families using diversification to extract private benefits at the expense of minority shareholders (Claessens et al., 1999c). The act of diversification is seen as an entrenched behaviour of controlling families.

The effect of firm diversification on performance can be quantified by using the coefficients reported in the table. For instance, the NUM_SEG coefficient of $-0.354(-0.026)$ with ROA (Tobin's Q) as the performance measure means that every additional increase in the number of business segments reduces ROA (Tobin's Q) by $0.354 \%$ (0.026). Thus, ROA (Tobin's Q), for a firm with five business segments, for instance, will be $1.77 \%$ (0.13) lower 
than firms with a single business segment (Note 6). This is translated into ROA (Tobin's Q) of 19\% (15\%) lower than firms with a single business segment (Note 7).

The insignificance of diversification dummy (DVSF_D) in both ROA and Tobin's Q suggests that performance of firms is not related to whether a firm is categorized as a focused firm or a diversified firm per se. It is rather the level of firm diversification that has an important impact on firm performance. The fact that a firm with nine business segments is treated as equivalent to a firm with two business segments in the DVSF_D dummy (both are assigned dummy value =1) may explain the insignificance of DVSF_D on firm performance. Thus, our findings support Hypothesis $1 \mathrm{~b}$ but not Hypothesis 1a.

Since firms affiliated to business groups are more diversified than their non-group counterparts as pointed out earlier, our finding is consistent with the call by some researchers such as Chang (2006) that business groups and their affiliates should limit their business portfolios in order to maintain focus on their core business area. This is an important lesson for family-controlled business groups as well as independent firms in Malaysia because as the institutional settings, including the capital markets, are improving, it will be increasingly difficult to reap the alleged benefits of diversification. As reasoned by Charkrabarti et al. (2007), positive outcomes of firm diversification are only possible in the most underdeveloped institutional environments. Thus, the fact that Malaysia's capital market is more developed (compared to many other emerging economies such as Thailand and Indonesia) (Singh and Zainal, 2005; Claessens et al., 2000) may offer an explanation for the negative outcome of diversification in this study.

\subsection{Analysis for Specification 2: Diversification and Asset Utilization}

We hypothesized earlier that corporate firm diversification among many Malaysian family-controlled firms is agency-driven (caused largely by principal-principal agency problems). Our findings on this issue are presented in Tables $4 \mathrm{a}$ and $4 \mathrm{~b}$ below. It should be noted that the dependent variable in this case is asset turnover ratio or asset utilization [proxy to agency costs as per Ang et al. (2000) and Florackis (2008)].

Table 4a. Influence of firm diversification on firm efficiency

\begin{tabular}{|c|c|c|c|c|}
\hline & (1) & (2) & (3) & (4) \\
\hline ENTROPY & $-0.405 * * *$ & & & \\
\hline HERF & & $0.641 * * *$ & & \\
\hline NUM_SEG & & & $-0.098 * * *$ & \\
\hline DVSF_D & & & & $-0.244 * * *$ \\
\hline $\mathrm{ROA}$ & $0.034 * * *$ & $0.034 * * *$ & $0.034 * * *$ & $0.035 * * *$ \\
\hline Group & $-0.266 * * *$ & $-0.272 * * *$ & $-0.265 * * *$ & $-0.287 * * *$ \\
\hline Adjusted $\mathrm{R}^{2}$ & 0.579 & 0.574 & 0.573 & 0.565 \\
\hline F-statistic & $24.885 * * *$ & $24.367 * * *$ & $24.285 * * *$ & $23.542 * * *$ \\
\hline Observations & 314 & 314 & 314 & 314 \\
\hline
\end{tabular}

Note: 1 . $^{*}$ significant at $10 \%$;** significant at $5 \%$; ***significant at $1 \%$.

2. The values in the table show the coefficients of the variables.

3. Control variables and sector effects are included in the regression (not shown above except for ROA and 'Group').

Table 4b. Firm diversification and efficiency: comparison between group and non-group firms

\begin{tabular}{|c|c|c|c|c|c|c|c|}
\hline & Group & & & Non-Gr & & & \\
\hline Variable & (1) & (2) & (4) & (5) & (6) & (7) & (8) \\
\hline ENTROPY & $-0.439 * * *$ & & & $-0.156^{*}$ & & & \\
\hline HERF & & $0.714 * * *$ & & & $0.234 *$ & & \\
\hline NUM_SEG & & & $-0.108 * * *$ & & & -0.024 & \\
\hline
\end{tabular}




\begin{tabular}{lllllllll}
\hline DVSF_D & & \multicolumn{3}{c}{$-0.331 * * *$} & & -0.095 \\
\hline ROA & $0.046^{* * *}$ & $0.046^{* * *}$ & $0.046^{* * *}$ & $0.048^{* * *}$ & $0.027 * * *$ & $0.027 * * *$ & $0.026^{* * *}$ & $0.027 * * *$ \\
\hline Adjusted $\mathrm{R}^{2}$ & 0.463 & 0.455 & 0.454 & 0.446 & 0.748 & 0.747 & 0.745 & 0.747 \\
\hline F-statistic & $8.616^{* * *}$ & $8.355^{* * *}$ & $8.340^{* * *}$ & $8.111^{* * *}$ & $29.117 * * *$ & $29.008 * * *$ & $28.741 * * *$ & $28.978^{* * *}$ \\
\hline Observations & 151 & 151 & 151 & 151 & 162 & 162 & 162 & 162 \\
\hline
\end{tabular}

Note: $1 . *$ significant at $10 \% ; * *$ significant at $5 \% ; * * *$ significant at $1 \%$.

2. The values in the table show the coefficients of the variables.

3. Control variables and sector effects are included in the regression (not shown above except for ROA).

All four measures of firm diversification in Table 4a show that there is a highly significant negative relationship between asset utilization and firm diversification. In other words, the higher the firm diversification, the less efficient is the asset utilization. Our finding thus offers an explanation for the negative performance outcome of diversification found earlier. The negative influence of firm diversification on asset utilization suggests that severe wastages of assets/resources caused by agency problems occur alongside firm diversification. Our finding is consistent with the findings in Ang et al. (2000), Fleming et al. (2005) and Chu (2007). Instances of resource expropriation, manager-owners' entrenchment and other activities that enhance only the interests of controlling families cause adverse effects on firm efficiency and performance. A controlling family may try to convince its shareholders that there is a need to diversify but instead use diversification activities to justify the move to retain more earnings and invest in considerable amounts of assets to increase opportunities to expropriate the assets/resources of the firm. These include asset tunneling and asset transfer, asset purchase and asset selling at non-market price, assets swap and other unfair insiders' asset transactions. According to Faccio et al. (2001), the reluctance to pay higher dividends and the tendency to retain more earnings among firms in Asia indicates their readiness to expropriate.

\subsection{Analysis for Specification 2: Testing the Effect of Group-Affiliation}

Splitting the sample into group-affiliated firms and non-group firms in Table $4 \mathrm{~b}$ reveals that the negative relationship between firm diversification and asset utilization stems mainly from firms which are business group affiliated, as the relationship is highly significant at $1 \%$, compared to a much weaker significant level in non-group firms. The finding implies that group-affiliated firms are more prone to greater agency-driven diversification than the non-group firms.

For the robustness of our result, we also ask the question whether there is a link between the negative effect of diversification on asset utilization observed mostly among the group-affiliated firms and the performance of these firms, compared to the non-group firms. We tested earlier and included the dummy variable 'group' with the finding presented in Table 3 that the group-affiliated firms significantly underperformed the non-group firms. Thus, we believe that poor asset utilization among the group-affiliated firms due to their excessive diversification is a main cause for the underperformance of group-affiliated firms compared to the non-group firms.

Our finding is consistent with arguments posed by researchers such as Young et al. (2008), Claessens et al. (2006), La Porta et al. (2003) and Khanna and Rivkin (2001) that the more complex structures of business groups over non-group firms provide more opportunities for controlling families to capture more private benefits through diversification and expansion. Bae et al. (2002) also show that diversification by acquisitions among Korean business groups (chaebols) is used by controlling shareholders as a way to increase their own wealth at the expense of other shareholders. Expropriatory intra-group and insiders' asset transactions that lead to lower efficiency of asset utilization occur more frequently in group-affiliated firms than in non-group firms. Overall, this finding, together with the previous finding, supports Hypothesis 2.

\subsection{Analysis for Specification 3}

Our examination of the moderating role of board independence on the diversification outcome shows that the dummy variable 'All Audit Committee Members are Independent Directors' (INDP_ADT) proves to be statistically significant in positively moderating the influence of diversification on firms' performance [see the interaction terms in Model (2) in Table 5a and 5b] (Note 8). However, Proportion of Independent Directors (INED) is found to be insignificant in moderating the diversification-performance relationship. At the first look, it may apparently implies that the extent of percentage of independent directors in family-controlled boards in Malaysia does not carry any positive influence on the performance outcome of diversification. However, from the information on mean of 0.43 
and standard deviation of 0.11 provided in Panel $\mathrm{C}$ of Table 2, the proportion of independent directors in majority of the family boards falls within a relatively small range of one-third to one-half. In addition, most (statistically ninety five percent) of the family-controlled firms have less than two-third independent directors in their boards. Hence, perhaps a much wider spread of percentage of independent directors, particularly with a good number of firms with at least two-third independent directors in their boards, will allow us to test the moderating effect of INED more objectively.

Table 5a. Firm diversification and ROA: influence of board independence

(1) (2)

\begin{tabular}{lll}
\hline Panel A: Entropy & & \\
\hline Entropy & -1.109 & $-2.397^{* *}$ \\
\hline Entropy*INED & -2.462 & $3.904^{* *}$ \\
\hline Entropy* INDP_ADT & & \\
\hline INED & -3.915 & $-2.218^{*}$ \\
\hline INDP_ADT & & 0.271 \\
\hline Adjusted R & & \\
\hline F-statistic & 0.266 & $7.476^{* * *}$ \\
\hline Observations & $7.291 * * *$ & 314 \\
\hline Panel B: Number of Segments & 314 & $-0.697^{* *}$ \\
\hline NUM_SEG & -0.323 & \\
\hline NUM_SEG *INED & 0.899 & $1.274^{* * *}$ \\
\hline NUM_SEG*INDP_ADT & & $-3.957^{* *}$ \\
\hline INED & -7.480 & 0.277 \\
\hline INDP_ADT & & $7.669^{* * *}$ \\
\hline Adjusted R & & 314 \\
\hline F-statistic & 0.267 & $7.324 * * *$ \\
\hline Observations & 314 & \\
\hline
\end{tabular}

Notes: $1 . *$ significant at $10 \%$;** significant at $5 \%$; ***significant at $1 \%$.

2 . The values in the table show the coefficients of the variables.

3. Control variables and sector effects are included in the regression (not shown above).

Table 5b. Firm diversification and Tobin's Q - influence of board independence

(1) (2)

\begin{tabular}{lll}
\hline Panel A: Entropy & & \\
\hline Entropy & $-0.083^{* *}$ & $-0.102^{* *}$ \\
\hline Entropy*INED & -0.147 & \\
\hline Entropy* INDP_ADT & & $0.049^{*}$ \\
\hline INED & -0.062 & \\
\hline INDP_ADT & & -0.073 \\
\hline Adjusted R & 0.177 & 0.181 \\
\hline F-statistic & $4.789^{* * *}$ & $4.847^{* * *}$ \\
\hline
\end{tabular}




\begin{tabular}{lll}
\hline Observations & 314 & 314 \\
\hline Panel B: Number of Segments & & \\
\hline NUM_SEG & $-0.026^{* *}$ & $-0.034^{* * *}$ \\
\hline NUM_SEG *INED & -0.015 & \\
\hline NUM_SEG*INDP_ADT & & $0.027^{*}$ \\
\hline INED & -0.085 & \\
\hline INDP_ADT & & $-0.126^{*}$ \\
\hline Adjusted R & 0.179 & 0.187 \\
\hline F-statistic & $4.797^{* * *}$ & $4.998^{* * *}$ \\
\hline Observations & 314 & 314 \\
\hline
\end{tabular}

Notes: $1 . *$ significant at $10 \% ; * *$ significant at $5 \% ; * * *$ significant at $1 \%$.

2. The values in the table show the coefficients of the variables.

3. Control variables and sector effects are included in the regression (not shown above).

The significant positive moderating influence of INDP_ADT is found to be capable of reversing the apparently negative relationship between diversification and performance. For instance, the Entropy coefficient of -2.397 [see Model (2) in Panel A of Table 5a] indicates that firm performance is negatively related to diversification. However, with the interaction term coefficient of 3.904, which is greater than 2.397, it suggests that when a firm's audit committee members are all independent directors, it is possible to reverse the negative relationship between firm diversification and performance to a positive one. The net effect is computed as $3.904+(-2.397)=1.507$ which can be interpreted as follows: for every 0.1 increase in the Entropy value, the ROA will improve by $0.15 \%$ in firms with INDP_ADT.

Similarly, with 'Number of Business Segments' (NUM_SEG) as the diversification measure [see Model (2) of Panel B in Table 5a], the net effect of diversification (with INDP_ADT as the moderator) on firm performance is computed as $1.274+(-0.697)=0.577$ which can be interpreted as follows: an increase in every business segment is associated with an improved ROA of $0.58 \%$ in firms with INDP_ADT. The positive moderating influence of INDP_ADT is also found when Tobin's Q is used as the performance measure, albeit at a weaker significant level.

We believe that with audit committee consists of all independent outside directors, the overseeing and monitoring of matters such as financial reporting \& disclosure process, internal control, risk management practices (Note 9), hiring and performance of external auditors, regulatory compliance and ethics pertaining to diversification related activities such as asset transfer, asset purchase and asset selling, assets swap, and insiders' asset transactions will be substantially enhanced. This should subsequently keep the agency-driven activities of firm diversification in check, curb over-diversification and possibly turn diversification into value added activities that improve firms' returns and maximize firms' value.

In short, our finding suggests that a board's audit committee, composed entirely of independent directors, may be the solution to improve the firm diversification-performance relationship. The finding supports Chen and Chen (2012) who find a significant positive relationship between audit committee quality and investment efficiency of diversified firms. Their study shows a reduced 'diversification discount' in firms associated with high quality audit committees which is proxied by two distinct measures, one of which is 'audit committee composed entirely of independent directors'.

Moreover, it is important to highlight that the 99 firms in ours study achieve the status of 'board audit committee composed entirely of independent directors' on a voluntary basis. This indicates that these firms may be more genuinely committed to maintaining independence, at least in their audit committees. The outcome might be different if authorities were to force the rules that firms must have fully independent audit committees, as without firstly addressing the issue of objectivity in the nomination, appointment and removal process of independent directors, enforcing rules will only result in compliance with the 'form' but not the 'substance' of independence. This is consistent with the view of the CFA Institute (2010) that one of the major obstacles to finding truly independent 
directors in Asia is related to the current process of nominating and appointing independent directors which does not preclude controlling shareholders from interfering in the process.

\section{Conclusion and Suggestion for Future Study}

Our findings surrounding firm diversification show that in general, diversification is not beneficial for the minority shareholders of family-controlled firms in Malaysia as increases in firm diversification are associated with deteriorating firm return and performance. This is particularly true for group-affiliated firms. The finding is in line with the explanation by Singh et al. (2007) that the probability of agency-driven and thus value-destroying diversification is greater in situations where the market for corporate control is inactive and where the corporate sector is dominated by family-controlled business groups and concentrated family ownership. The finding thus implies that principal-principal agency costs of diversification in family-controlled firms in Malaysia outweigh diversification benefits of resource-based view as explained by Martin and Sayrak (2003). Our finding that diversification performance is worse in group-affiliated firms than in non-group firms is also consistent with Lins and Servaes's (2002) and Chakrabarti's et al. (2007) proposal that there is a lack of valid reasons to diversify at the firm level when the task can be more efficiently fulfilled at the group level. Further evidence reveals that the poor performance outcome of firm diversification may be explained by the poor efficiency of asset utilization. The low efficiency of asset utilization could well be a manifestation of substantial agency costs borne by the firms as per Ang's et al. (2000) proposal [and later followed by others such as Fleming et al. (2005) and Florackis (2008)].

The issue of corporate firm diversification is associated with takeover policy. The generally unfavourable outcomes of firm diversification in this study imply that diversification is pursued by controlling families for the consumption of private benefits which adversely impacts firm efficiency and performance. This suggests that there may be weaknesses in the regulation of takeovers and disclosure requirements on transactions between bidder and seller as well as the disclosure requirements of diversification. Controlling families could increase firm diversification through takeovers that increase the probability of minority shareholder oppression such as misallocation of resources, transfer pricing and insider trading. The impact of takeovers on corporate diversification performance is left for future study.

We also do not separate firm diversification into related and unrelated diversification. Since the unfavourable performance outcomes of diversification as reported in this study imply that diversification of firms is agency-driven, future work can examine whether such diversification outcomes are sensitive to the separation of related and unrelated diversification. This illuminates whether unrelated diversification is more agency-driven than related diversification. Future study could also examine whether there is a difference in the level of related and unrelated diversification between group-affiliated firms and unaffiliated firms $(\mathrm{Ng}, 2015)$. Such a finding may clarify why the diversification outcome of group-affiliated firms is generally worse than that of non-group firms as found in this study.

Last but not the least we also find that firms in which the board's audit committee is fully occupied by independent outside directors positively moderate the effect of diversification on firm performance. This finding is comparable to Chen and Chen (2012) who find a significant positive relationship between the investment efficiency of diversified firms and an audit committee composed entirely of independent directors. Our finding is also in line with Lu and Wang (2015) who find that board independence is negatively associated with non-R\&D capital investments but positively associated with $R \& D$ investments.

We believe that independent outside directors could play an important and effective role if they are given a free hand to carry out their duties within their legitimate scope as seen in the case of the independent audit committees of the family-controlled firms. These firms, in turn, should be given incentives and sufficient awareness by the regulators on the long lasting benefits of board independence (from the controlling family and management) to a firm's return and value. In short, an audit committee's fully independent status achieved on a voluntary basis implies a firm's commitment to a higher governance standard in not only form but substance also. The monitoring effort of such an audit committee is thus more effective in reducing agency-driven diversification and promoting prudent diversification decisions.

\section{References}

Al-Maskati, N., Bate, A. J., \& Bhabra, G. S. (2015). Diversification, corporate governance and firm value in small markets: evidence from New Zealand. Accounting \& Finance, 55(3), 627-657.

Amihud, Y., \& Lev, B. (1981). Risk reduction as a managerial motive for conglomerate mergers. Rand Journal of Economics, 12, 605-617. https://doi.org/10.2307/3003575 
Amihud, Y., \& Lev, B. (1999). Does corporate ownership structure affect its strategy towards diversification?.

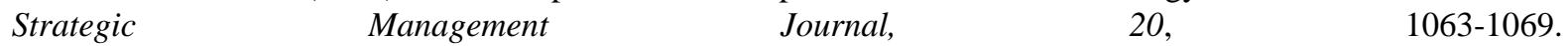
https://doi.org/10.1002/(SICI)1097-0266(199911)20:11<1063::AID-SMJ69>3.0.CO;2-S

Anderson, R. C., \& Reeb, D. M. (2003). Founding family ownership and firm performance: evidence from the S\&P 500. Journal of Finance, 58(3), 1301-1328. https://doi.org/10.1111/1540-6261.00567

Anderson, R. C., Bates, T. W., \& Bizjak, J. M. (2000). Corporate governance and firm diversification. Financial Management, 29, 5-22. https://doi.org/10.2307/3666358

Andres, C. (2008). Large shareholders and firm performance - an empirical examination of founding family ownership. Journal of Corporate Finance, 14, 431-445. https://doi.org/10.1016/j.jcorpfin.2008.05.003

Ang, J., Cole, R., \& Lin, J. (2000). Agency costs and ownership structure. Journal of Finance, 55(1), 81-106. https://doi.org/10.1111/0022-1082.00201

Ayoib, C. A., Ishak, Z., \& Manaf, N. A. (2003). Corporate governance, ownership structure and corporate diversification: Evidence from the Malaysian listed companies. Asian Academy of Management Journal, 8(2), 67-89.

Bae, K. H., Kang, J. K., \& Kim, J. M. (2002). Tunneling or valued added: Evidence from mergers by Korean business groups. Journal of Finance, 62(6), 2695-2740. https://doi.org/10.1111/1540-6261.00510

Baran, L., \& Forst, A. (2015). Disproportionate insider control and board of director characteristics. Journal of Corporate Finance, 35(1), 62-80. https://doi.org/10.1016/j.jcorpfin.2015.08.006

Bru, L., \& Crespi-Cladera, R. (2006). Diversification of family business groups and board control. SSRN Working Paper, Social Science Research Network. https://doi.org/10.2139/ssrn.924845

Bruton, G., Ahlstrom, D., \& Wan, J. (2003). Turnaround in East Asian firms: Evidence from ethic overseas Chinese communities. Strategic Management Journal, 24, 519-540. https://doi.org/10.1002/smj.312

CFA Institute. (2010). Independent non-executive directors: A search for true independence in Asia. Asia-Pacific Office of the CFA Institute Centre for Financial Market Integrity, CFA Institute, Charlottesville.

Chakrabarti, A., Singh, K., \& Mahmood, I. (2007). Diversification and performance: Evidence from East Asian firms. Strategic Management Journal, 28, 101-120. https://doi.org/10.1002/smj.572

Chang, S. J. (2006). Business groups in East Asia: Post-crisis restructuring and new growth. Asia Pacific Journal of Management, 23, 407-417. https://doi.org/10.1007/s10490-006-9013-4

Chen, R., Dyball, C. M., \& Wright, S. (2009). The link between board composition and corporate diversification in Australian corporations. Corporate Governance: An International Review, 17(2), 208-223.

Chen, S. S., \& Chen, I. J. (2012). Corporate governance and capital allocations of diversified firms. Journal of Banking \& Finance, 36, 395-409. https://doi.org/10.1016/j.jbankfin.2011.07.013

Chen, S. S., \& Ho, K. W. (2000). Corporate diversification, ownership structure, and firm value: the Singapore evidence. International Review of Financial Analysis, 9, 315-326. https://doi.org/10.1016/S1057-5219(00)00032-6

Chu, E. Y. (2007). Ownership Structure, Rent Seeking and Performance: Evidence from the Malaysian Manufacturing Sector (1994-2000). Unpublished PhD Thesis, Universiti Sains Malaysia, Penang.

Chu, E. Y., \& Song, S. I. (2011). Large shareholder, capital structure and diversification: Evidence from Malaysian manufacturing firms. African Journal of Business Management, 5(14), 6005-6010.

Claessens, S., \& Fan, J. (2002). Corporate governance in Asia: a survey. International Review of Finance, 3(2), 71-103. https://doi.org/10.1111/1468-2443.00034

Claessens, S., Djankov, S., \& Lang, L. H. P. (1998a). East Asian corporates: growth, financing and risks over the last decade. World Bank Working Paper Series, World Bank.

Claessens, S., Djankov, S., \& Lang, L. H. P. (2000). The separation of ownership and control in East Asian corporations. Journal of Financial Economics, 58, 81-112. https://doi.org/10.1016/S0304-405X(00)00067-2

Claessens, S., Djankov, S., Fan, J., \& Lang, L. H. P. (1998b). Diversification and ffficiency of investment by East Asian corporations. World Bank Working Paper, World Bank. https://doi.org/10.2139/ssrn.147467 
Claessens, S., Djankov, S., Fan, J., \& Lang, L. H. P. (1999). Corporate diversification in East Asia: the role of ultimate ownership and group affiliation.World Bank Policy Research Working Paper No. 2089, World Bank.

Claessens, S., Djankov, S., Fan, J., \& Lang, L. H. P. (2002). Disentangling the incentive and entrenchment effects of large shareholdings. Journal of Finance, 57(5), 2741-2771. https://doi.org/10.1111/1540-6261.00511

Claessens, S., Djankov, S., Fan, J., \& Lang, L. H. P. (2003). When does corporate diversification matter to productivity and performance? Evidence from East Asia. Pacific-Basin Finance Journal, 11, 365-92.

Claessens, S., Fan, J., \& Lang, L. H. P. (2006). The benefits and costs of group affiliation: evidence from East Asia. Emerging Markets Review, 7, 1-26. https://doi.org/10.1016/j.ememar.2005.08.001

Demsetz, H., \& Lehn, K. (1985). The structure of corporate ownership: causes and consequences. Journal of Political Economy, 93, 1155-1177. https://doi.org/10.1086/261354

Denis, D. J., Denis, D. K., \& Sarin, A. (1997). Agency problems, equity ownership, and corporate diversification. Journal of Finance, 52, 135-160. https://doi.org/10.1111/j.1540-6261.1997.tb03811.x

Denis, D. J., Denis, D. K., \& Sarin, A. (1999). Agency theory and the influence of equity ownership on corporate diversification strategies. Strategic Management Journal, 20, 1071-1076.

Douma, S., George, R., \& Kabir, R. (2006). Foreign and domestic ownership, business groups, and firm performance: evidence from a large emerging market. Strategic Management Journal, 27, 637-657.

Faccio, M., Lang, L. H. P., \& Young, L. (2001). Dividends and expropriation. American Economic Review, 91, 54-78. https://doi.org/10.1257/aer.91.1.54

Fatimah, A. B. (2001). Corporate governance in financial troubled companies. Paper Presented at the Seminar on Corporate Governance: Issue and Challenges, Universiti Utara Malaysia, Sintok.

Fauver, J. H., \& Naranjo, A. (2003). Capital market development, international integration, legal systems, and the value of corporate diversification: a cross-country analysis. Journal of Financial and Quantitative Analysis, 38(1), 135-157. https://doi.org/10.2307/4126767

Fleming, G., Heaney, R., \& McCosker, R. (2005). Agency costs and ownership structure in Australia. Pacific-Basin Finance Journal, 13, 29-52. https://doi.org/10.1016/j.pacfin.2004.04.001

Florackis, C. (2008). Agency costs and corporate governance mechanisms: evidence for UK firms. International Journal of Managerial Finance, 4(1), 37-59. https://doi.org/10.1108/17439130810837375

García-Kuhnert, Y., Marchica, M. T., \& Mura R. (2015). Shareholder diversification and bank risk-taking. Journal of Financial Intermediation, 24(4), 602-635. https://doi.org/10.1016/j.jfi.2015.03.001

George, R., \& Kabir, R. (2008). Business groups and profit redistribution: a boon or bane for firms?. Journal of Business Research, 61, 1004-1014. https://doi.org/10.1016/j.jbusres.2007.12.002

Gleason, K., Kim, I., Kim, Y. H., \& Kim, Y. S. (2012). Corporate governance and diversification. Asia-Pacific Journal of Financial Studies, 41(1), 1-31. https://doi.org/10.1111/j.2041-6156.2011.01065.X

Gomez, E. T. (2006). Malaysian business groups: the state and capital development in the post-currency crisis period. In Chang S. (Ed.), Business Groups in East Asia: Financial Crisis, Restructuring, and New Growth. Oxford University Press, Oxford. https://doi.org/10.1093/acprof:oso/9780199287345.003.0006

Gomez, E. T., \& Jomo, K. S. (1997). Malaysia's Political Economy: Politics, Patronage, and Profits. Cambridge University Press, Cambridge.

Guest, P., \& Sutherland, D. (2010). The impact of business group affiliation on performance: evidence from China's 'national champions'. Cambridge Journal of Economics, 34, 617-631. https://doi.org/10.1093/cje/bep017

Haniffa, R. M., \& Hudaib, M. (2006). Corporate governance structure and performance of Malaysian listed companies. Journal of Business Finance and Accounting, 33(7-8), 1034-1062. https://doi.org/10.1111/j.1468-5957.2006.00594.X

Jacquemin, A., \& Berry, C. (1979). Entropy measure of diversification and corporate growth. Journal of Industrial Economics, 27, 359-70. https://doi.org/10.2307/2097958

Jensen, M. C. (1986). Agency costs of free cash flow, corporate finance, and takeovers. American Economic Review, 76, 323-329. 
Jiang, F., Jiang, Z., Kim K. A., \& Zhang M. (2015). Family-firm risk-taking: does religion matter?. Journal of Corporate Finance, 33(1), 260-278. https://doi.org/10.1016/j.jcorpfin.2015.01.007

Khanna, T., \& Palepu, K. (2000a). Is group affiliation profitable in emerging markets? An analysis of diversified Indian business groups. Journal of Finance, 55, 867-891. https://doi.org/10.1111/0022-1082.00229

Khanna, T., \& Palepu, K. (2000c). The future of business groups in emerging markets: long run evidence from Chile. Academy of Management Journal, 43, 268-285. https://doi.org/10.2307/1556395

Khanna, T., \& Rivkin, J. (2001). Estimating the performance effects of business groups in emerging markets. Strategic Management Journal, 22, 45-74.

Kim, K. H., Al-Shammari, H., Kim, B., \& Lee, S-H. (2008). CEO duality leadership and corporate diversification behavior. Journal of Business Research, 62(11), 1173-1180. https://doi.org/10.1016/j.jbusres.2008.10.017

Krejcie, R., \& Morgan, D. (1970). Determining sample size for research activities. Educational and Psychological Measurement, 30, 607-610. https://doi.org/10.1177/001316447003000308

La Porta, R., Lopez-De-Silanes, F., \& Shleifer, A. (1999). Corporate ownership around the world. Journal of Finance, 54(2), 471-517. https://doi.org/10.1111/0022-1082.00115

La Porta, R., Lopez-de-Silanes, F., \& Zamarripa, G. (2003). Related lending. Quarterly Journal of Economics, 118(1), 231-268. https://doi.org/10.1162/00335530360535199

Lang, L., \& Stulz, R. (1994). Tobin's Q, corporate diversification, and firm performance. Journal of Political Economy, 102, 1248-1280. https://doi.org/10.1086/261970

Lewellen, W. G. (1971). A pure financial rationale for the conglomerate merger. Journal of Finance, 26, 527-537.

Lien, Y., \& Li, S. (2013). Does diversification add value in emerging economies? Effect of corporate governance. Journal of Business Research, 66(12), 2425-2430. https://doi.org/10.1016/j.jbusres.2013.05.030

Lins, K. V. (2003). Equity ownership and firm value in emerging markets. The Journal of Financial and Quantitative Analysis, 38(1), 159-184. https://doi.org/10.2307/4126768

Lins, K. V., \& Servaes, H. (2002). Is corporate diversification beneficial in emerging markets?. Financial Management, 31, 5-31. https://doi.org/10.2307/3666220

Lu, J., \& Wang, W. (2015). Board independence and corporate investments. Review of Financial Economics, 24, 52-64. https://doi.org/10.1016/j.rfe.2015.01.001

Mak, Y. T., \& Kusnadi, Y. (2005). Size really matters: further evidence on the negative relationship between board size and firm value. Pacific-Basin Finance Journal, 13, 301-318. https://doi.org/10.1016/j.pacfin.2004.09.002

Martin, J. D., \& Sayrak, A. (2003). Corporate diversification and shareholder value: a survey of recent literature. Journal of Corporate Finance, 9, 37-57. https://doi.org/10.1016/S0929-1199(01)00053-0

Masulis, R. W., Pham, P. K., \& Zein, J. (2011). Family business group around the world: financing advantages, control motivations, and organizational choices. The Review of Financial Studies, 24(11), 3556-3600.

Mehmood, R., Hunjra, A., \& Chani, M. (2019). The Impact of Corporate Diversification and Financial Structure on Firm Performance: Evidence from South Asian Countries. Journal of Risk and Financial Management, 12(1), 49-66. https://doi.org/10.3390/jrfm12010049

Mitton, T. (2002). A cross-firm analysis of the impact of corporate governance on the East Asian financial crisis. Journal of Financial Economics, 64, 215-241. https://doi.org/10.1016/S0304-405X(02)00076-4

$\mathrm{Ng}$, S. H. (2015). Effects of Corporate Group Affiliation to Firm Performance in Malaysia. Journal of Finance \& Financial Services, 2, 15-37.

$\mathrm{Ng}$, S. H., \& Yeoh, K. (2012). Corporate governance in Malaysia: a glass half full?. Indian Journal of Corporate Governance, 5(2), 120-132. https://doi.org/10.1177/0974686220120203

Ng, S. H., Yeoh, K., Lau, C. K., \& Shrives, P. (2012). Factor influencing the performance of family-controlled, publicly-listed firms in Malaysia. Review of Integrative Business \& Economics Research, 1(1), 179-206.

Palepu, K. (1985). Diversification strategy, profit performance and the entropy measure. Strategic Management Journal, 6(3), 239-255. https://doi.org/10.1002/smj.4250060305 
Palich, L. E., Cardinal, L. B., \& Miller, C. C. (2000). Curvilinearity in the diversification performance linkage: an examination of over three decades of research. Strategic Management Journal, 21, 155-174.

Robins, J., \& Wiersema, M. (2003). The measurement of corporate portfolio strategy: analysis of the content validity of related diversification indexes. Strategic Management Journal, 24(1), 39-59. https://doi.org/10.1002/smj.282

Ross, S. A., Westerfield, R. W., \& Jaffe, J. (2015). Corporate Finance (11th ed.). McGraw-Hill International Edition, Singapore.

Salkind, N. J. (2010). Encyclopedia of Research Design. SAGE Publications, London. https://doi.org/10.4135/9781412961288

Singh, M., \& Davidson, W. N. III (2003). Agency costs, ownership structure and corporate governance mechanisms. Journal of Banking \& Finance, 27, 793-816. https://doi.org/10.1016/S0378-4266(01)00260-6

Singh, M., Nejadmalayeri, A., \& Mathur, I. (2007). Performance impact of business group affiliation: an analysis of the diversification-performance link in a developing economy. Journal of Business Research, 60, 339-347.

Singh, R., \& Zainal, Y. (2005). Development of the capital market in Malaysia. In Vandenbrink, D., \& Hew, W. (Eds.), Capital Markets in Asia: Changing Roles for Economic Development. ISEAS Series, ISEAS.

Suto, M. (2003). Capital structure and investment behaviour of Malaysian firms in the 1990s: a study of corporate governance before the crisis. Corporate Governance, 11(1), 25-39. https://doi.org/10.1111/1467-8683.00299

Thillainathan, R. (1999). Corporate governance \& restructuring in Malaysia - a review of markets, mechanisms, agents \& the legal infrastructure. Paper Prepared for the Joint World Bank/OECD Survey of Corporate Governance Arrangements in a Selected Number of Asian Countries.

Wilson, N., Wright, M., \& Scholes, L. (2013). Family business survival and the role of boards. Entrepreneurship Theory and Practice, 37(6), 1369-1389. https://doi.org/10.1111/etap.12071

Young, M. N., Peng, M. W., Ahlstrom, D., Bruton, G. D., \& Yi, J. (2008). Corporate governance in emerging economics: a review of the principal-principal perspective. Journal of Management Studies, 45(1), 196-220. https://doi.org/10.1111/j.1467-6486.2007.00752.x

Zuaini, I., \& Napier, C. (2006). Expropriation of minority interests and corporate diversification in Malaysia. Asian Academy of Management Journal of Accounting and Finance, 2, 85-113.

\section{Notes}

Note 1. Corporate governance reform took place in Malaysia with the release of the Malaysian Code on Corporate Governance in 2000.

Note 2. Besides Tobin's Q and ROA, ROE is another performance measure that is widely used. As a robustness check, we examined some of the hypotheses in this study using ROE as the performance measure and found that the findings remain qualitatively similar to the findings based on ROA.

Note 3. Information on whether a director is independent is disclosed in the company annual report. The Bursa Malaysia Listing Requirements define an independent director as a person who is not involved in the management of the firm and does not have any direct or indirect interest.

Note 4. For instance, we use White's standard errors to correct the presence of heteroscadasticity

Note 5. We actually calculated the Variance Inflation Factors (VIFs) for a small number of explanatory variables that show comparatively higher correlations between themselves but did not find any serious multicollinearity between the variables (our VIFs tolerance level is set at 4.00).

Note 6. Five business segments x $0.354 \%=1.77 \%$ for ROA; five business segments x $0.026=0.13$ for Tobin's Q.

Note 7. The calculation is based on the mean ROA (mean Tobin's Q) of $9.19 \%(0.87)$ in the sample: $(1.77 \% / 9.19 \%)$ $=0.19$ for $\operatorname{ROA}$ and $(0.13 / 0.87)=0.15$ for Tobin's $\mathrm{Q}$.

Note 8. Our findings using Herfindahl index are relatively similar and is not shown here.

Note 9. Risk management comes under the role of the audit committee as most of the family-controlled firms in Malaysia do not set up a separate risk management committee in the board of directors. 